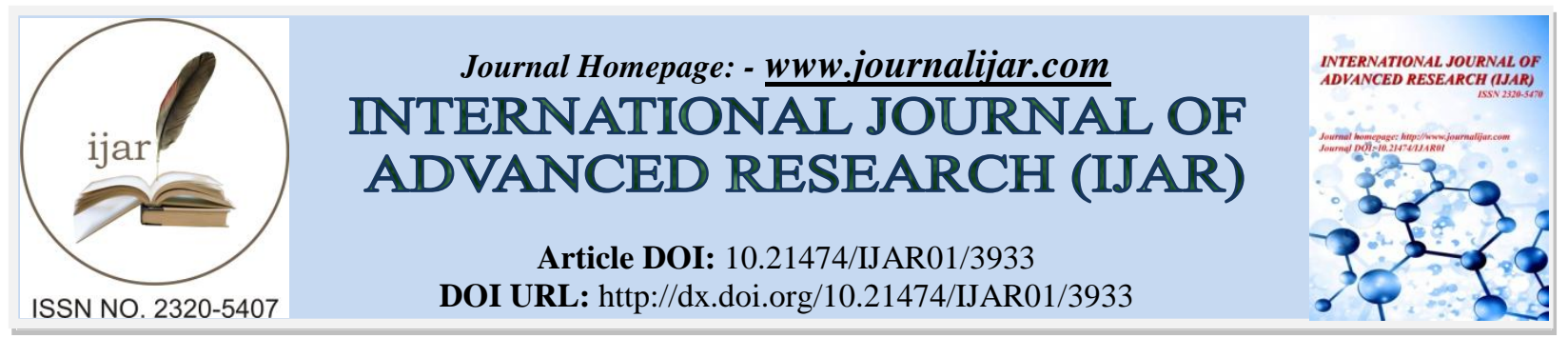

RESEARCH ARTICLE

\title{
ROLE OF PHALATRIKADI GHRITHA IN SIMPLE MYOPIA.-A CASE STUDY
}

\author{
Kalpana s wakode. \\ Associate Professor In Shalakyatantra Govt Ayurvedic College Nanded.
}

\section{Manuscript Info}

Manuscript History

Received: 20 February 2017

Final Accepted: 21 March 2017

Published: April 2017

Key words:-

Myopia, Phalatrikadighritha, Tarpana

\begin{abstract}
Eyes are Gods greatest gift so requires proper care and protection.Eyes are windows to our soul. The visual defact was considered as Timira the dristigatrogas in vedic literature that is in Sushrutsamhita. .MYOPIA is optical defect which interferes with comfortable vision. Eyes are excessively taxed due to profession requiring more visual strain, more exposure to television, computer screen sleep disturbances ill nourishing diets etc .It is linked with excessive close work in school going children. Myopia which is generally regarded as an inconvenience, is infact a major cause of visual impairment among young adults of working age .It has been stated in ancient literature that timira i.e. is defective vision like myopia can be cure by doing application of tarpana ,ashchotana ,etc kriyakalpas. And in myopia therapeutic effect can be found by tarpana. The ingredients of phalatrikadighrith i.e. trifala is chakshushya and rasayan .shatavari and yashtimadhu is chakshushya and bruhana in properties. Ghee being shrestha agnivardhak and madhu being yogvahi togetherly acts over simple myopia.
\end{abstract}

Copy Right, IJAR, 2017,. All rights reserved.

\section{Introduction:-}

Eyes are the greatest and valuable God's gift .we should always take care and protect them .vision damages directly or indirectly from number of causes i.e. from infections, trivial trauma, degenerations malnutrition etc. The direct cause of visual loss are cataract, glaucoma and refractive errors i.e. myopia ,hypermetropia astigmatism and pressbyopia .These are major problems for visual health individuals. The visual defect was considered as Timira the drishtigatrogas in vedic literature SHUSHRUT SAMHITA .Even when myopia does threaten sight ,it imposes limits on career choices. Thus myopia which is generally regarded as an inconvenience is infact a major cause of visual impairment and blindness among young adults of working age.

In modern medicine refrective correction is the only management and laser therapy is substituted to it which is highly expensive. At present spectacles are the more popular curative measures. Contact lenses is another solution but it troublesome wearing ,handling difficulties and fear of corneal infection force to avoid it .As all these managements are available medicinal treatment is awaited or there is no scope for medicinal therapeutics .In ancient literature it is stated that timira i.e. defective vision like myopia can be cure by doing application of tarpana. While working in OPD it has been observed number of patients of simple myopia and there questioning for herbal medicinal treatment. so to observe the role of alternative medicines it is decided to determine the therapeutic effect of phaltrikadighrithatarpan as a part of treatment in timira w.s.r. to simple myopia. The ingredients of phaltrikadigritha i.e Triphala is popular remedy used in eye disease. Shatavari and Yashtimadhuare chakshushya 
and bruhana in property. Ghritha being shreshthaagnivardhak and madhu being yogvahi togetherly acts on simple myopia.ghritha is considered as best drug of tarpana as it is yogvahi and sanskaranuwarti.ghritha is specified as chakshushya, rasayan madhur in rasa with madhurvipaka ,sheet virya tridoshaghna and useful in increasing oja and teja.

\section{Case Study:-}

A 23 year old male hindu by religion, student came to our OPD of our hospital having complains of discomfort in eyes, eye strain, and headache with difficulty in distant vision since 3 months .he was having mild complains since 8 months but gradually from 3 months complains are increasing he is taking modern medicine and using spects he was given but still because of his type of work on computers and smart phones he was not getting rid of his symptoms. so he came to our hospital for alternative medicines. and the patient was examined his distant vision was less i. e. 6/12 and in addition with symptoms.

\section{Diagnosis:-}

The condition was diagnosed as simple myopia.

\section{Management and Observations:-}

Considering this condition as simple myopia .Myopia is tridoshaja having vata predominance andshaithilyajanya .so it can be well treated by vatakaphaghna ,pittagnivardhak, dhatupushtikar rasayana. PhalatrikadighrithaTarpanatarpana was done in each eye with the medicated gritha as per the required dose in the morning with proper pre and post procedure as per mentioned in the text for two months. Along with the medications he was advised pathyapathya for ex. not to read in dark, blinking frequently especially while working on computers and phones, avoid spicy food, fermented food, delayed slipping etc. and to take good nutritious diet. The patient follow this treatment advised to him for 2 months and there was marked relief in symptoms i.e. discomfort in eyes, eye strain and headache and the vision was improved. He was advised for pathyapathya continuously.

\section{Discussion:-}

Myopia is controversial subject regarding the treatment, modern sciences explains only optical corrections and laser therapy now a days. On the contrary Ayurveda has explained medicinal therapy applicable in the form of Kriyakalpa. In myopia there is dimness of vision for distance, sings of eye strain i..e lacrimation discomfort and headache laxity of outer coat of eyeball (kaphakshyajashaithilya). Eye ball is larger than normal size (vatajvyas).Dimness of vision suggests Aalochak pitta dushti.hence there is vata predominance alpakaphadushti with aalochakapittadushti. As it is prathama and dwitiyapatalgat disease i.e. tejojalashrit and mansashrit it includes Rasa Rakta and mansadushya. so the principle of treatment is tridoshaghna pittagnivardhak balya Rasayan Chakshushya Rasa Rakta Mansa dushtihar. Tarpan provides sufficient time for local drug absorption and eliminates morbid doshas in eye siras. There was improvement in visual acuity, sings of asthenopia and reduction in required lenses is much better.

\section{Conclusion:-}

Phalatrikadigritha tarpana is effective in simple myopia ,it is safe economical and easy to Perform. It is beneficial as its marked relief over symptoms. Also no adverse reaction has been reported during treatment. The study concludes that Phalatrikadigritha tarpana is effective in management of simple myopia.

\section{Reference:-}

1. ShushrutSamhita - Dulhantika- chaukhamda publication

2. A text book of shalakyatantra part -1 Vidhavans

3. SushrutsamhitaUttartantra by Dr. Anant Ram Sharma, Varanasi.

4. Dravyagunavigyan-AcharyaP. Sharma-chaukhamba publication Banaras

5. Clinical ophthalmology Kanski Jack .J. London. 